New Legal Orders: The Challenges of European Integration and International Human Rights 



\section{Between Cosmopolis and Community: Justice and Legitimacy in a European Union of Peoples

\author{
Richard Bellamy*
}

\section{Introduction}

Two apparently contradictory trends characterise contemporary European politics. On the one hand, there has been both a widening of the EU to include the countries of Central and Eastern Europe, and increasingly the Baltic and the Balkans as well, and calls for its deepening - especially in the wake of the Euro crisis - with greater political unification promoted in many quarters as a necessary complement to monetary union and the single market. On the other hand, there are growing pressures towards devolution and secession within many established states as minority national groups reassert a desire for selfdetermination. There is also mounting disaffection towards the EU across Europe, with rising support for populist parties - particularly but not exclusively on the right.

The second trend often gets compared somewhat negatively to the first trend, to which it is seen as an anachronistic and regressive reaction. From this perspective, the second trend represents an ultimately doomed attempt to escape the realities and obligations of an ever more interconnected world associated with the first trend, and to withdraw into the parochial and divisive nationalisms of the past. This analysis has both an empirical and a related normative aspect, whereby the process of globalisation raises the need and possibility for more global forms of legal and political organisation grounded in cosmopolitan principles that recognise the equal moral status of all individuals, regardless of their national, ethnic,

\footnotetext{
* Research for this chapter was supported by a Leverhulme Trust Research Fellowship RF-2012-368, which was largely written while a Fellow of the Hanse-Wissenschaftskolleg in Delmenhorst. I am grateful to Dario Castiglione, Sandra Kröger and Christine Reh for their comments on an earlier version.
} 
religious or cultural affiliations. ${ }^{1}$ The move towards greater European integration is alleged to reflect this new reality. The EU may often fail to meet these emerging global challenges and cosmopolitan ideals, but for a number of its most prominent political and academic advocates it is the belief that only a body such as the EU has the potential to do so effectively that provides the best rationale for the integration process.

The empirical aspect of this way of thinking was well expressed by the then President of the European Council, Herman von Rompuy, when asked his opinion on what was at that time only a proposed referendum on Scottish independence:

Nobody has anything to gain from separatism in the world of today which, whether one likes it or not, is globalised ... We have so many important challenges to take and we will only succeed if we can pool forces, join action, take common directions. The global financial crisis is hitting us hard. Climate change is threatening the planet. How can separatism help? The word of the future is union. ${ }^{2}$

In a similar vein, the philosopher Jürgen Habermas has remarked how, in his view, 'financial markets' and 'more generally, the functional systems of world society, whose influence permeates national borders, are giving rise to problems that individual states, or coalitions of states, are no longer able to master'. ${ }^{3}$ As a result of this 'need for regulation' on a global scale, he contends 'the international community of states must develop into a cosmopolitan community of states and world citizens'.

As Habermas' remark indicates, the normative aspect of the integrative thesis has been considered as intimately associated with the empirical aspect. This position has also figured prominently in the discourse of EU officials. As the former President of the European Commission, José Barroso, declared in a seminar on 'Global Constitutionalism':

The present crisis has shown the limits of individual action by nation states. Europe and the principles of the Treaty need to be renewed. We need more integration, and the corollary of more integration has to be more democracy. This European renewal must represent a leap in

\footnotetext{
${ }^{1}$ D Held, Democracy and the Global Order: From the Modern State to Cosmopolitan Governance (Cambridge, Polity Press, 1995).

${ }^{2}$ Herman von Rompuy, speaking in an interview of June 2011, as reported in D Boffey, 'European chief pours scorn on Scottish independence' The Guardian (4 November 2012).

${ }^{3} \mathrm{~J}$ Habermas, The Crisis of the European Union: A Response (Cambridge, Polity, 2012) xi.

4 ibid xi.
} 
quality and enable Europe to rise to the challenges of the world today by giving it the tools it needs to react more effectively and to shape and control the future. ${ }^{5}$

In other words, he contends the functional need for greater integration has as its by-product a normative spill-over that allows for and requires greater democratic accountability at the European and ultimately at the global level. On this account, global problems can only be legitimately tackled by invoking global norms, that themselves imply more global legal and democratic arrangements. The EU provides the most developed example at the regional level of such a post-national arrangement.

Once again, Habermas provides a good academic example of this line of argument. He maintains the very idea of human rights involves 'an implicit claim that equal rights for everyone should be implemented on a global scale'. Moreover, this 'cosmopolitan claim' is not just a moral claim that motivates the critique of global injustice but also a legal claim for the constitutionalisation of international law, since 'human rights rely on finding institutional embodiment in a politically constituted world society'. ${ }^{6}$ As a result, he contends that the 'sustained political fragmentation in the world and in Europe is in contradiction to the systemic growth of a global multi-cultural society'. ${ }^{7}$ In Habermas' view, the just and effective resolution of the Euro crisis requires a move towards a new form of social and political solidarity built on a commitment to human rights and the concomitant rejection of the outmoded categories of national identity and state sovereignty that he believes block moves towards a Union based on democracy and social justice rather than the market.

Both the empirical and normative strands of these arguments for greater EU integration have undeniable force. Any empirically plausible or normatively acceptable account of politics must acknowledge both the global issues currently confronting contemporary societies and the moral responsibilities owed to non-nationals. In an increasingly interconnected world, problems such as global warming, the fair regulation of international

\footnotetext{
${ }^{5}$ European Commission, 'Quotes from the speech by the President of the European Commission, José Manuel Durão Barroso, at the occasion of Yale's Global Constitutionalism Seminar convening at The Hague' European Commission Press Release (Brussels, 1 September 2012).

${ }^{6}$ Habermas, Crisis of the European Union (n 3) xi-xii.

7 ibid 7.
} 
trade and severe poverty in developing countries cannot be ignored. To the extent that many Eurosceptic arguments appear to do so, they seem practically deficient and morally reprehensible. Yet, it would be wrong to regard all arguments that seek to understand the EU and global governance more generally in broadly international rather than cosmopolitan terms as indifferent to either global problems or norms of global justice and human rights. Rather, they seek to combine respect for these issues and values with forms of legal and political organisation that also give weight to some of the concerns underlying the second trend noted above, and the associated desire to retain power at, or possibly devolve it below, the level of established nation-states, rather than to transfer it to a supranational body above them.

A more sympathetic reading of this second trend notes that it too can be linked to empirical features of contemporary societies and supported by normative values of a communitarian character that reflect the self-understandings of liberal democratic states. ${ }^{8}$ From this perspective, the second trend arises from the importance of self-government among people who are mutually interdependent in a number of significant respects, share various common interests and norms, and seek to promote trust and support for collective arrangements that make sense to them as appropriate and are responsive to their interests and values. As the quotes given above illustrate, many of those who regard the EU as a necessary functional response to globalisation also contend it allows for new forms of self-government that can satisfy these demands through the democratic control of processes that increasingly operate between and across states. Yet, continuing complaints about the EU's democratic deficit indicate how difficult this contention has proven to put into practice. More importantly, it also ignores the tensions that can arise between regional integration and the historical political identities and forms of communal self-rule that have developed within

\footnotetext{
${ }^{8}$ In other words, communitarianism is understood here not as a set of policy recommendations but as an ontological account of the normative basis of liberal democratic states as provided by liberal nationalists such as Yael Tamir and David Miller. See Y Tamir, Liberal Nationalism (Princeton NJ, Princeton University Press, 1993) and D Miller, On Nationality (Oxford, Clarendon Press, 1995). On the 'ontological'/'advocacy' distinction, we follow C Taylor, 'Cross-Purposes: The Liberal-Communitarian Debate' in N Rosenblum (ed), Liberalism and the Moral Life (Cambridge Ma, Harvard University Press, 1989) 159-60.
} 
each of the Member States - a tension that has become increasingly prominent in recent years. ${ }^{9}$

This chapter explores the cosmopolitan and the international routes to meeting the twin challenges thrown up by the two trends of globalisation and cosmopolitan justice, on the one hand, and the continued communitarian demands for forms of national self-determination that combine popular with polity sovereignty on the model of the nation-state, on the other. The EU is often seen as awkwardly placed between the two, its governance structures caught between representing citizens and representing states, ${ }^{10}$ on the one hand, and developing a trans- or supranational public interest and reflecting the mutual interests of the component nation states, on the other. ${ }^{11}$ Many supporters of European integration believe that this situation is impractical and incoherent. They contend the only plausible and justifiable solution is to resolve the second trend into the first and to make the EU the primary locus of political identity and self-determination for European citizens. ${ }^{12}$ By contrast, I wish to suggest that these two trends can be brought together in a less reductive way that gives equal weight to each of them. I shall argue that the EU is best seen as a locus of deep cooperation between self-governing nation-states, which serves in many respects as a means of maintaining rather than replacing them in the new global context.

Two conceptual distinctions inform this analysis and are developed in the rest of this chapter. The first relates to the distinction between cosmopolitanism and communitarianism, which I link to the first and second trends respectively. Within this analysis, they represent contrasting ontological rather than ideological positions that offer different understandings of the normative and empirical basis for broadly liberal egalitarian and democratic values. I

\footnotetext{
${ }^{9}$ L Hooghe and G Marks, 'A Postfunctionalist Theory of European Integration: from Permissive Consensus to Constraining Dissensus’ (2009) 39(1) British Journal of Political Science 1.

${ }^{10}$ S Kröger and D Friedrich, 'Democratic Representation in the EU: Two Kinds of Subjectivity' (2013) 20(2) Journal of European Public Policy 171.

${ }^{11}$ R Bellamy and D Castiglione, 'Three Models of Democracy, Political Community and Representation in the EU' (2013) 20(2) Journal of European Public Policy 206.

12 eg S Hix, What's Wrong with the European Union and How to Fix It (Cambridge, Polity, 2008) and A Duff, Federal Union Now (London, Federal Trust, 2011).
} 
shall argue that the one favours an instrumental view of political community, the other an intrinsic view. ${ }^{13}$ According to the first, instrumental view, both the design and competences of democratic institutions and the size and location of the political communities in which they operate should be determined by whatever scheme proves most appropriate to deliver effective and equitable policies in the most efficient manner. ${ }^{14}$ Though some grant the modern nation-state may prove convenient for certain purposes, ${ }^{15}$ others regard both state and popular sovereignty as undermining impartial principles of justice and favour their radical dispersal across a variety of political units. ${ }^{16}$ Analogous reasoning informs the neofunctionalist interpretation of the integration process which underlay the Monnet method and still provides the background assumptions behind much of the Commission's thinking. According to this thesis, the acquisition of competences by the EU induces a spill-over effect linked to functional efficacy, which both leads the EU to move into ever more related policy areas and in time encourages the shift to the European level of political institutions and ultimately people's allegiances and identities as well. ${ }^{17}$

By contrast, the second, intrinsic view, regards the good of being an equal member of a democratic polity as possessing an independent value. In such a community, citizens participate as equals in making those collective decisions in which, taken as a whole, they have an equal stake. The terms on which they participate are formally and to a degree substantively the same for all, and they treat each other as equals within the process of decision-making. Such a view of political community rests on a degree of mutual

\footnotetext{
${ }^{13}$ On this distinction, see A Mason, Living Together as Equals: The Demands of Citizenship (Oxford, Oxford University Press, 2012) chs 1 and 2.

${ }^{14}$ eg P Van Parijis, Just Democracy: The Rawls-Machiavelli Programme (Colchester, ECPR Press, 2013) chs 1, 5 and 7 .

${ }^{15}$ RE Goodin, 'What is So Special about Our Fellow Countrymen?' (1988) 98 Ethics 663.

${ }^{16}$ T Pogge, 'Cosmopolitanism and Sovereignty' in T Pogge, World Poverty and Human Rights 2nd edn (Cambridge, Polity, 2008) ch 7.

17 E Haas, The Uniting of Europe: Political, Social and Economic Forces 1950-57 (Stanford, Stanford University Press, 1958).
} 
identification stemming from shared interests and values among its members, qualities that are fostered by a history of mutual interactions among them. ${ }^{18}$

If one applies this distinction to the two trends outlined above, it may be that the empirical and normative arguments made by the EU officials and philosophers cited earlier offer a case for an instrumental political community at the European level, but they fall short of justifying an intrinsic political community. That might be thought unimportant. As we saw, some cosmopolitan advocates of global justice regard such an intrinsic community as outmoded, unnecessary and in certain respects unpleasant and unjustified as well as impractical. However, the contention shall be that cosmopolitanism cannot overcome or replace the communitarian impulse, not least because reasons linked to justice and function per se underdetermine the level and membership of any political community.

The second distinction I wish to draw enters here: that between justice and legitimacy. ${ }^{19}$ Once again, I adopt a broadly liberal egalitarian conception of these concepts. In formal terms, one can define the former as giving each their due according to a given principle of justice, and the latter as indicating that institutions are recognised as rightfully ruling over those to whom they apply. While related, in that the perceived justice of a regime is likely to be a contributing factor to its legitimacy, the one cannot be regarded as providing criteria for the other. Beyond the formal contours of the concept of justice, considerable reasonable disagreement exists as to what giving someone his or her due entails. ${ }^{20}$ Different theories of justice, even within the same family of theories - such as Rawls' and Dworkin's respective liberal egalitarian accounts - offer different views of what a person is owed from the state and other citizens. Nevertheless, states have to institute and enforce some view or set of

\footnotetext{
${ }^{18}$ eg the intrinsic image of political community informs David Miller's advocacy of national self-determination. See the account of 'radical democracy' in D Miller 'Democracy's Domain' (2009) 37(3) Philosophy and Public Affairs 201 and more generally Miller, On Nationality (n 8).

${ }^{19}$ On this distinction see P Pettit, On the People's Terms: A Republican Theory and Model of Democracy (Cambridge, Cambridge University Press, 2012) 130-31; L Valentini, 'Assessing the Global Order: Justice, Legitimacy or Political Justice?' (2012) 15(5) Critical Review of International Social and Political Philosophy 593, 594-95.

${ }^{20}$ J Waldron, Law and Disagreement (Oxford, Oxford University Press, 1999) 1, 199.
} 
views. The notion of legitimacy enters here. The state's right to rule involves that those subject to it accept its authority. Many criteria might be given for such acceptance, including a historical and cultural identification with a given political community. Within liberal democracies, though, such acceptance has typically rested on the state providing citizens with reasons to believe that it treats them as equals. In the absence of any commonly accepted epistemology capable of giving objective reasons for a given group of people to accept a given set of policies as equitable, these accounts conclude that the available reasons will be those linked to their having participated on equal terms in a political process to determine those policies. Therefore, a legitimate state will need to sustain democratic practices. As a result, the commitment of citizens to a political community takes on an independent weight it cannot be instrumental to serving ends that it plays an intrinsic part in determining. The grounds for political community will need to be investigated in their own terms, as raising separate normative and empirical conditions to those that might justify their possible reconfiguration or collaboration to tackle issues related to globalisation and justice.

Such considerations prove crucial to any investigation of the current and prospective democratic legitimacy of the EU. They provide the ontological grounds for the 'polity' aspect of the EU, and the degree to which it can be regarded as involving an ever closer union of peoples or the formation of a European people. The rest of this chapter explores the distinctions between an instrumental and an intrinsic political community, on the one side, and between justice and legitimacy, on the other. I shall argue that the legitimacy of particular cosmopolitan conceptions of justice can only be determined by political communities with sufficient intrinsic qualities to be able to support a democratic regime. As a result, the most normatively desirable and empirically feasible way of conceiving the EU polity is in what can be called cosmopolitan communitarian terms. Such a political ontology treats the EU as a union of European peoples with a cosmopolitan regard for tackling the problems of a globalising world in ways that mutually support the capacity of these different demoi to sustain a democratic political community.

\section{The Communitarian Ghost in the Cosmopolitan Machine}

This section outlines more fully than above the normative and empirical strands running through the cosmopolitan and communitarian arguments. As we shall see, these two strands 
determine the model of the EU each school of thought regards as desirable and feasible respectively. The differences between the two views relate in their turn to the contrasting ways cosmopolitans and communitarians conceive of the relationship of rights and citizenship, on the one hand, to popular and state sovereignty, on the other. Whereas cosmopolitans seek to divorce the former from the latter, communitarians contend the latter necessarily frames the former - a contention we shall link in the next section with the way in which considerations of justice raise in their turn questions of legitimacy.

\section{A. Cosmopolitan Globalists and Federalists}

Following Brian Barry, one can define the normative basis of cosmopolitanism as resting on three elements: that individual human beings have ultimate value; that each individual human being has equal moral value; and that these two conditions apply to all human beings. ${ }^{21}$ Most cosmopolitans are keen to distinguish moral from legal and political cosmopolitanism. For example, Charles Beitz has written that 'cosmopolitanism need not make any assumptions at all about the best political structure for international affairs'. ${ }^{22}$ However, these claims notwithstanding, cosmopolitans do seek to constrain the ways political institutions, however configured, operate so as to ensure they treat 'every human being' as having 'global stature as an ultimate unit of moral concern'. ${ }^{23}$ This argument has taken a number of forms, and is compatible with both a utilitarian and a deontological, rights-based morality, amongst other moral doctrines.

The significance of this constraint can be seen if one considers what might be ruled out by this approach. Clearly, it rules out valuing people according to features such as their race or gender. Yet it also has been held to rule out a partiality to compatriots or according

\footnotetext{
${ }^{21}$ B Barry, 'Statism and Nationalism: a Cosmopolitan Critique' in I Shapiro and L Brilmayer (eds), Nomos: Global Justice (New York, New York University Press, 1999) 35-36.

${ }^{22}$ C Beitz, 'International Relations, Philosophy of' in E Craig (ed), The Routledge Encyclopaedia of Philosophy vol 4 (London, Routledge, 1998) 831.

${ }^{23}$ Pogge, 'Cosmopolitanism and Sovereignty’ (n 16) 175.
} 
value to collective entities such as states. The argument goes that being born into a given country is a matter of simple good or bad fortune and as morally arbitrary as having a certain colour or being born into a given class. ${ }^{24}$ The difficulty such arguments face is spelling out what exactly they mean in practice. ${ }^{25}$ They are held to suggest that we should value all individuals equally, but exactly in what ways - be it through global equality of opportunity, global equality of resources or global equality of some other good - is unclear.

Two reasons explain this difficulty. One reason, explored later in the chapter, is that the significance of particular resources and opportunities is subject to different evaluations within different cultures or in different circumstances, rendering it hard to make the meaningful comparisons between different societies that are required to decide whether they are equal in some relevant respect or not. ${ }^{26}$ The second and related reason is that the claim that all individuals should be treated as moral equals, and the assertion that national belonging is as morally arbitrary as hair colour, does not in itself explain in what ways, if at all, they should be treated equally. As David Miller notes, a person with congenital disabilities suffers from differences that are morally arbitrary, but most would regard this circumstance as providing grounds for special, and hence unequal, treatment that is not morally arbitrary. A substantive reason is needed to show why national belonging is like hair colour rather than disability, and what that entails in practice. ${ }^{27}$

The standard substantive counter-argument for nationality not being morally arbitrary in determining the opportunities and resources that are open to people has been that people in national political communities have special relationships to one another that they do not have

\footnotetext{
${ }^{24}$ eg C Beitz, 'Cosmopolitan Ideals and National Sentiment' (1983) 80 Journal of Philosophy 591, 593, 595; T Pogge, 'An Egalitarian Law of Peoples' (1994) 23 Philosophy and Public Affairs 195, 196, 198; S Caney, 'Cosmopolitan Justice and Equalizing Opportunities' (2001) 32 Metaphilosophy 113, 115, who argues 'this reasoning is, I believe, either explicitly or implicitly present in almost all defences of cosmopolitanism' (115 fn 3); D Moellendorf, Cosmopolitan Justice (Boulder CO, Westview, 2002) 78-80.

${ }^{25}$ D Miller, 'Against Global Egalitarianism' (2005) 9 The Journal of Ethics 55.

${ }^{26}$ B Boxhill, 'Global Equality of Opportunity and National Integrity' (1987) 5 Social Philosophy and Policy 143; Miller, ‘Against Global Egalitarianism' (n 25) 60-63.
}

${ }^{27}$ Miller (n 25) 68-69. 
to others elsewhere. Indeed, a cosmopolitan notion of equal respect might even justify acknowledging that citizens of a community should give priority to equalising the conditions of their co-nationals over equalising conditions between members of different, even very unequal, countries. ${ }^{28}$ As a result, some cosmopolitan theorists have wished to suggest that relationships among people at the regional and global level are becoming more like relations between people within nations.

These considerations in part motivate Pogge's well-known proposal that we should cash out the implications of cosmopolitan morality in institutional rather than interactional terms: as applying to the rules and procedures of certain institutional schemes, rather than as pertaining to the actions of individual persons and agencies. ${ }^{29}$ He notes how the interactional case is practically weaker than the institutional in a number of respects. Take the case of rights, from which he argues. The perfect obligations necessary to uphold negative rights of non-interference can be conceptualised in global terms reasonably easily, since in principle at least they are costless and simply require individual forbearance. It is much harder to assign a global responsibility for positive rights to care and welfare that appear to rely on special obligations. Indeed, in the absence of any causal relation for the potential or actual harms involved, it is difficult even to justify positive action to secure negative rights worldwide, through the supply of peace-keeping forces and the like. The institutional view appears to fill this lacuna, since it potentially links us to a whole range of unknown others and provides a duty even to safeguard those negative rights we have not personally violated. The focus here is no longer on the direct relations between individuals, but on the justice of the practices and arrangements within which people are involved and for which they are jointly and severally responsible.

However, this institutional argument is contingent on the possible or actual existence of a global institutional scheme within which we all participate to some significant degree. ${ }^{30}$

\footnotetext{
${ }^{28}$ RW Miller, 'Cosmopolitan Respect and Patriotic Concern' (1998) 27(3) Philosophy and Public Affairs 202.

${ }^{29}$ Pogge (n 16) 176-77. cp, say, with the 'interactionist' argument in S Caney, Justice Beyond Borders: A Global Political Theory (Oxford, Oxford University Press, 2005) 78.

${ }^{30}$ The exposition of this thesis in the next three paragraphs derives from Held, Democracy and the Global Order (n 1) chs 5 and 6.
} 
The socio-political strand of the cosmopolitan argument comes in here. Global socioeconomic forces are held to have created a greater degree of interconnectedness within the world than ever before. Technological advances have internationalised production, distribution and exchange and transformed financial markets. Multinational corporations (MNCs), even when they possess a regional or national base, are said to organise their affairs on an international scale and respond to global market pressures. This internationalisation of markets is even more apparent in the financial sector, where new information technology has radically increased the mobility of economic units and to a large degree tied the world's major banking and trading centres into a single integrated network. New communications systems have also rendered ordinary people more aware of these global developments than ever before. The media, according to proponents of this thesis, have altered the 'situational geography' of social and political life by giving people direct access to distant events and creating new experiences, commonalties and frames of meaning that do not require direct physical contact - popular reactions to Tiananmen Square and the plight of the Kurds in the aftermath of the Gulf War being good examples of this phenomenon. A series of common cultural references - from the banality of soap operas through to greater popular awareness and knowledge of world events - have allegedly generated new solidarities as evidenced in transnational social movements such as Greenpeace and Amnesty International.

The above mentioned processes are claimed to have weakened in turn the capacity of nation-states to provide for the security and welfare of their citizens, and led to the creation of a number of international power blocks, agencies, organisations, regimes and networks to facilitate their continued ability to do so by managing various areas of transnational activity. These institutions range from collective security arrangements such as NATO, through a variety of other intergovernmental bodies of different degrees of formality aimed at controlling various aspects of economic and social policy. Some are purely technical agencies and limited in scope, like the Universal Postal Union or the World Meteorological Association, others more politically contentious organisations with a potentially profound impact on core domestic policies, such as the IMF and World Bank. Some constitute international regimes with very broad competences and complex governance structures, such as the UN, the Council of Europe and the EU, others more informal global networks, such as the G7. All these organisations modify the freedom of action of states to one degree or another and undercut their capacity to operate as sovereign units. Consequently, their title to act as the agents of the sovereign will of their people has been likewise eroded. Effective 
decision-making and the sources of identification has in many cases passed elsewhere, or so at least it is alleged.

Finally, this move beyond the sovereign nation-state is reflected in the body of international law that has grown up in the wake of these developments. Here individuals are gradually replacing states as the main subjects of the law. On the one hand, it has been recognised that individuals have rights and obligations that are independent of and go beyond those duties and entitlements they have as citizens of particular states - a point made most strikingly in war crime trials. On the other hand, the legitimacy of states has come to rest as much on the justice of their rule as on their de facto hold on power. The post-war international declarations of rights have reinforced this shift from state to individual, as have challenges to the notions of 'immunity from jurisdiction' and 'immunity from state agencies' which have hitherto operated as central principles of international law.

This global positivisation of individual moral rights brings the normative and empirical strands of the cosmopolitan thesis together. As we saw, it informs Habermas' view of the EU as a stage towards the embodiment of human rights in a legally and politically constituted world society. In fact, at least two broad possible views of the EU can follow from this perspective. One version holds that the forces described above have undermined the nation-state, but that a centralised federal Europe, that is itself not unlike a nation-state writ large, can fill the gap. ${ }^{31}$ Another, more truly cosmopolitan, version is not so much supranational as post-national in orientation, ${ }^{32}$ viewing moves towards federalism as an alternative to, rather than a new form of, the unitary sovereign state. ${ }^{33}$ By and large, political scientists - especially those of a functionalist disposition - have been drawn towards the first position. They have advocated the strengthening of the Union's supranational features particularly the European Parliament and the Commission - and the phasing out of

\footnotetext{
${ }^{31}$ eg Duff, Federal Union Now (n 12).

${ }^{32}$ eg JH Ferry, 'Une "philosophie" de la communaute' in JH Ferry and P Thibaud (eds), Discussion sur l'Europe (Paris, Calmann-Levy, 1992) 179-89; J. Habermas, The Inclusion of the Other, (Cambridge: Polity, 1999); pp. 105-127 and, more generally, The Postnational Constellation (Cambridge: Polity, 2000)

${ }^{33} \mathrm{O}$ Beaud, 'La Fédération entre l'état et l'empire' in B Thèret (ed), L'État, la finance et le sociale (Paris, La Decouverte, 1995).
} 
intergovernmentalism, and have welcomed the move towards common policies in the spheres of domestic justice and foreign affairs in addition to economic and social matters. ${ }^{34}$ Lawyers, by contrast, have been the principal advocates of the second position. They have drawn inspiration from the gradual development of a single legal framework by the Court of Justice of the European Union (CJEU), noting with approval its increasing tendency to appeal to human rights and its claims of Supremacy over the domestic law of Member States and Direct Effect with regard to their citizens. ${ }^{35}$ Needless to say, the reality falls far short of either version of the cosmopolitan ideal - a fact that communitarians are not slow in pointing out.

\section{B. Communitarians, Liberal and Civic Nationalists and the Sovereignty of States}

Communitarians question both the normative and empirical aspects of the cosmopolitan thesis. With regard to the normative aspect, they dispute the global egalitarianism of the cosmopolitan case. That does not mean that they do not believe there are great injustices that arise from huge disparities in wealth between rich and poor countries and that these ought to be diminished. However, these disparities need not be decried on global egalitarian grounds. Among other reasons, they can be criticised as facilitating the domination of some states by

\footnotetext{
${ }^{34}$ E.g. S George, Policy and Politics in the European Community 2nd edn (Oxford, Oxford University Press, 1991); RO Keohane and S Hoffman, 'Institutional Change in Europe in the 1980s' in RO Keohane and S Hoffman (eds), The New European Community: Decision Making and Institutional Change (Boulder and Oxford, Westview Press, 1991); EO Eriksen, The Unfinished Democratization of Europe (Oxford, Oxford University Press, 2009) and A Giddens, Turbulent and Mighty Continent: What Future for Europe?, (Cambridge: Polity, 2014).

${ }^{35}$ Eg GF Mancini, 'The Making of a Constitution for Europe' (1989) 26 Common Market Law Review 595, D. Kostakopoulou, The Future Governance of Citizenship (Cambridge University Press, 2008), Armin von Bogdandy, 'The European Lesson for International Democracy: The Significance of Articles 9-12 EU Treaty for International Organizations'. (2012) 23 (2) European Journal of International Law 315, For the contrast between the legal and political science paradigms, see JHH Weiler, UR Haltern and FC Mayer, 'European Democracy and its Critique' in J Haywood (ed), The Crisis of Representation in Europe (London, Frank Cass, 1995) 24-33; D Wincott, 'Political Theory, Law and European Union' in J Shaw and G More (eds), New Legal Dynamics of European Union (Oxford, Clarendon Press, 1995).
} 
others. Rather, what communitarians object to is the coherence of pursuing policies that accord intrinsic value to reducing equality according to some metric, such as resources or opportunities, between individuals across the globe.

As we noted above, such metrics prove impossible to operationalise because they are interpreted differently within different cultural contexts. Take the notion of equal opportunity, understood as granting individuals of similar talents and motivations an equal chance to achieve certain positions regardless of which state they come from. Assuming that not all political communities have been merged, so that the provisions available worldwide are identical in all respects, this principle must mean that individuals in different countries have equivalent opportunities. Within nation-states agreement is reached on certain sorts of resource and opportunities being important, and rough equivalents exist to match regional variations. Equal access to sporting opportunities may be thought important, say, but that can mean cricket pitches in England and rugby pitches in Wales, for example. But when one makes cross-national and cultural comparisons, the exercise becomes much more complicated. For the priorities may be very different. The measure of a good education in country A may not be the same as in country B - they value different skills and operate in different contexts. ${ }^{36}$

Of course, there are also differences of opinion within national communities. However, there is an overarching social context within which they can be debated. The ways we view each other as equals is a function of the character of the society and the culture in which we live, and the goods we share. ${ }^{37}$ Therefore, the crucial factor is that we possess political equality in deciding and deliberating on the shape of that shared culture. A link is thereby established between national, popular and state sovereignty. Nationality defines a common political culture and identity that has developed historically through democratic control being tied to a state in ways that allow a people to determine for themselves the

\footnotetext{
${ }^{36}$ See Miller (n 25) 61-63.

${ }^{37}$ M Walzer, 'Philosophy and Democracy’ (1981) 9(3) Political Theory 379.
} 
relevant ways they are alike and unalike, and so deserving of equal or different treatment within the public sphere. ${ }^{38}$

Communitarians also contest the second, empirical, element of cosmopolitanism, questioning both the degree and consequences of the processes of globalisation and interconnectedness. It is possible to dispute, for example, the extent to which MNCs truly operate at a transnational level. As Hirst, Thompson and Bromley have shown, ${ }^{39}$ core capital, basic Research and Development, and management personnel and structures are mostly located within a main national base. The various political bodies and non-governmental agencies that have developed to cope with global problems of security and welfare tend to be inter-national and inter-governmental rather than supranational. The UN, for example, far from representing a nascent form of cosmopolitan governance, as is sometimes argued, ${ }^{40}$ remains very much an instrument of the sovereign states which compose it - not least the superpowers, whose hold on the Security Council effectively blocks any move that might damage their interests. ${ }^{41}$ Indeed, the major powers' effective control over the purse strings enables them to manipulate most important, and hence costly, initiatives requiring inter-state cooperation, and to stop those that do not meet with their approval - witness the sabotaging of UNESCO by Britain and the United States. ${ }^{42}$ More generally, the evidence that economic globalization has rendered the capacity of governments and states to make autonomous decisions that impact on the welfare of their citizens seem open to question. The share of global GDP consumed by States has never been greater, with State income expenditure actually positively correlated with economic openness rather than the other way round. ${ }^{43}$

\footnotetext{
${ }^{38}$ Miller, On Nationality (n 8) ch 4; M Walzer, Spheres of Justice: A Defence of Pluralism and Equality (Oxford, Martin Robertson, 1983) 28-29.

${ }^{39}$ P Hirst, G Thompson and S Bromley, Globalisation in Question 3rd edn (Cambridge, Polity, 2009).

${ }^{40}$ Held (n 1) pt IV.

${ }^{41}$ D Zolo, Cosmopolis: La prospettiva del governo mondiale (Milan, Feltrinelli, 1995) 27-28.

${ }^{42}$ RJB Jones, 'The United Nations and the International Political System' in D Bourantonis and J Weiner (eds), The United Nations in the New World Order: The World Organization at Fifty (Basingstoke, Macmillan, 1995).

${ }^{43}$ C. Hay, Why we Hate Politics, (Cambridge: Polity, 2007), ch 4.
} 
Cosmopolitans also are said to overlook the differential impact of global forces on different countries and the imbalances in the degree and nature of the interdependence that they create. By and large the wealthier and more powerful nations are net beneficiaries from global market forces, for example, whilst poorer states are either locked out of many of the networks or are subordinate partners and often damaged by global trade, becoming sources of cheap labour and resources, rather than developing strong economies of their own. Global environmental, health, security and other dangers that are no respecters of state borders are said to bind the peoples of the world together as sharing a common fate. However, they rarely affect all of them to an equal extent. When joint actions have shared consequences, such as the depletion of fish stocks, then cooperative action may be possible, although here too the standard free rider problems that arise with all public goods and bads mean that many countries will attempt to evade their responsibilities. Because the advantages and disadvantages are not usually mutual even with shared activities or problems, the incentives for cooperative behaviour are usually lopsided. ${ }^{44}$ Even within the EU, the substantial differences in economic performance, social standards and political interests between the Member States has rendered the formulation of common policies far from easy. Britain's acrimonious attempts to reduce the massive financial transfers to other EU states via the Common Agricultural Policy reflect a genuine problem, which potentially weakens the commitment to the Union of all the main contributors. ${ }^{45}$ The differential impact of the financial crisis within the Eurozone has revealed this problem in even more dramatic fashion, most notably in the ongoing tensions between the creditor and the debtor states.

Although states do form blocs for certain limited purposes, it is also important to note that these often have the goal of preserving state autonomy rather than diminishing it. Alan Milward's account of the former European Community as a 'rescue' of the nation-state is

\footnotetext{
${ }^{44}$ RJB Jones, Globalisation and Interdependence in the International Political Economy: Rhetoric and Reality (London and New York, Pinter, 1995) 75-77.

${ }^{45}$ Hirst, Thompson and Bromley, Globalisation in Question (n 39) ch 7; RJB Jones, 'The Economic Agenda' in G Wyn Rees (ed), International Politics in Europe: The New Agenda (London and New York, Routledge, 1993).
} 
highly pertinent in this respect. ${ }^{46}$ The EU emerges from this analysis as being, in part at least, a reaction against the forces of globalisation. Although the EU has drawn increasing criticism from those of a social democratic persuasion for promoting neo-liberal market policies that undermine domestic welfare and social corporatist measures, ${ }^{47}$ it has aroused parallel criticism from neo-liberal defenders of the free market on account of the Social Chapter, environmental and similar regulation. ${ }^{48}$ Arguably both views underestimate the EU's responsiveness to domestic political pressures in both directions, and the degree to which the core policies involving high government expenditure - social welfare provision, defence, education, culture and infrastructure - have hitherto remained outside its remit. ${ }^{49}$

For related reasons, more homogeneous consumption patterns and a greater awareness of world affairs has not necessarily produced as much convergence in political identity amongst the general population as cosmopolitans assert. People distinguish a humanitarian concern with famine or other disasters in countries other than their own from the sort of formalised responsibilities they have for co-nationals. They may support initiatives such as Band Aid or give to Oxfam, but that is a long way from condoning increased taxation to expand the development aid budget, say. Television, social media, faster communication systems, greater job mobility and the like, may have broadened people's horizons in certain respects and encouraged them to identify with a wider community, but the identification may not be as deep as the solidarities of old, based as they were on continuous, direct contact and personal involvement.

Just as I distinguished two different versions of the cosmopolitan ideal with regard to the EU, so two broad positions can be associated with communitarian thinking. On the one hand, there are conservative Eurosceptics of the British variety who think in terms of narrow national interests and conceive the nation in quasi-ethnic terms, resulting in a particularly

\footnotetext{
${ }^{46}$ A Milward, The European Rescue of the Nation-State (London and New York, Routledge, 1992).

${ }^{47}$ F Scharpf, ‘Legitimacy in the Multilevel European Polity’ (2009) 1 European Political Science Review 173.

48 J Rabkin, Why Sovereignty Matters (Washington, DC, AEI Press, 1998).

49 A Moravscik, 'Is there a Democratic Deficit in World Politics? A Framework for Analysis' (2004) 39(2)

Government and Opposition 351.
} 
hard line position on immigration for example. On the other hand, there are 'liberal' and civic nationalists. These can be more social democratic in ideology and influenced by republican notions linking patriotism with democratic participation, as in the French tradition. ${ }^{50}$ For different reasons, both groups will be reluctant to see a dilution of the intergovernmental character of the EU. However, whilst the first would dispute any shift in a federalist direction, the second merely argue that until such time as a global identity and public culture develops, moral weight has to be given to the self-determination of different peoples. Attempts to force the pace will be seen as unjustified, but certain moves of a cosmopolitan kind are possible even if the total transcendence of the nation-state remains highly unlikely. ${ }^{51}$

\section{Two Views of Rights, Citizenship, Democracy and Sovereignty}

Cosmopolitans and communitarians hold two different views of the nature of rights, citizenship, democracy and sovereignty and the ways they relate to each other. These differences partly reflect in their turn the contrast between an instrumental and an intrinsic view of political community noted earlier.

Cosmopolitans see rights as essentially self-standing. Their justification is independent of their recognition by any given society or culture and do not rely on democratic endorsement for their validity. Their scope and application is uniform and universal with individuals as their subjects. Citizenship and sovereignty are regarded as potentially antithetical to rights to the extent they link rights to membership of an already existing state rather than regarding them as attributes of human beings as such. Rather, than

\footnotetext{
${ }^{50} \mathrm{P}$ Thibaud, 'L'Europe par les nations (et réciproquement)' in Ferry and Thibaud (eds), Discussion sur l'Europe (n 32). Although see Miller, On Nationality (n 8) for a British version, especially ch 6.

${ }^{51}$ D Miller, 'Republicanism, National Identity and Europe' in C Laborde and J Maynor (eds), Republicanism and Political Theory (Oxford, Blackwell, 2008).
} 
being the source of rights, citizenship and sovereignty need to be refashioned to reflect rights. 52

Democracy plays an important role in this refashioning. On this account, democracy follows from a right to an equal opportunity for political participation. ${ }^{53}$ Where and with whom that right is exercised, and over what, should be matters of individual choice constrained by feasibility criteria. Thus, Pogge suggests that political units can be shaped and reshaped by a majority or supermajority of the inhabitants of contiguous territories provided the new and any remaining units remain viable and 'of reasonable shape', while any subgroups can reject membership of the new unit, form their own or merge with some other unit subject to these same criteria. ${ }^{54}$ At the same time, he advocates the vertical dispersal of sovereignty across a number of governance levels, from the international to the local. Again, rather loose, largely functional, criteria govern this dispersal of decision-making power. On the one hand, inclusiveness favours a centralisation of power, so that all significantly affected by decisions may be included. On the other hand, effective and equal participation in decision-making favours the decentralisation of power, so that individuals have the time, knowledge and opportunities to influence the social and political conditions that most immediately shape their lives. ${ }^{55}$ He regards the EU's system of multi-level governance as partly reflecting such a democratic vertical dispersal of sovereign power, with the reconfiguration of its constituent political units the natural next step. ${ }^{56}$

Such moves depend on the 'regime' features of a political system, its system of governance, being separable from its 'polity' features, the way a people and certain functions are defined as being governed by a given 'regime'. Cosmopolitans contend a variety of different transnational and supranational democratic decision-making processes can emerge

\footnotetext{
${ }^{52}$ Pogge (n 16) 184; J Carens, 'Aliens and Citizens: The Case for Open Borders' (1987) 49(2) Review of Politics 251.

${ }^{53}$ Pogge (n 16) 191.

${ }^{54}$ ibid 196-97.

55 ibid 184, 186, 191-95.

56 ibid 301 fn 282, 304 fn 386; T Pogge 'Creating Supra-National Institutions Democratically: Reflections on the European Union's Democratic Deficit' (1997) 5(2) Journal of Political Philosophy 163.
} 
that are respected simply because they reflect cosmopolitan norms. Such norms can be grounded in international law, particularly human rights law. Indeed, Habermas argues this is already the case within the EU. He notes how the CJEU claims 'competence-competence' to decide issues of European law and their impact on the Member States but has no power to enforce its decisions other than through the courts and administrative bodies of those same states. Many of those decisions, such as those relating to Union citizenship, establish transnational rights for individuals, including political rights to participate in EU elections wherever they reside. He regards this development as part of the process whereby law and democracy have become detached from state sovereignty, understood as a monopoly of coercive power over a given territory. Instead, he contends CJEU decisions are accepted because they are 'right'. 57

By contrast to this position, communitarians regard rights as being framed and upheld by citizenship and sovereignty. Given rights need to be interpreted and enforced, their security requires some agency that can do so in assured and impartial ways. That proves particularly true of property rights, which are partly conventional. ${ }^{58}$ All rights but especially those property rights that are in land create the need for a territorially based sovereign power. This power must possess a monopoly of coercive force not only within its borders but without them, in order stabilise the system of rights, including those of property ownership, and defend them against incursions from other powers.

Two consequences follow from the way sovereignty serves to define a 'polity' and the associated rights of its members. The first consequence is that so long as an individual's rights depend for their specification and protection on being subject to a territorially based sovereign political unit, then it will not be possible to fully stipulate those rights without reference to the individual's territorial affiliation in at least some instances. For example, with regard to issues of war and peace, the individual right to self-defence will be modified to involve the right to retaliate against an invading enemy army and - to the extent their

\footnotetext{
${ }^{57}$ Habermas, Crisis of the European Union (n 3) 23-28.

${ }^{58}$ A Stilz, Liberal Loyalty: Freedom, Obligation and the State (Princeton, Princeton University Press, 2009) 3444.
} 
activities support that army - the civilian population of an enemy. ${ }^{59}$ Note that the liberally minded statist communitarian does not dispute that individuals are in the ultimate analysis the holders of rights, on that point they agree with cosmopolitans, merely that the holding and exercise of these rights arise in the context of a specific political unit.

The second consequence follows from the first, in that the basis, nature and limits of an individual's obligations towards this unit become a key issue from this perspective. Communitarians contend that coercive institutions must operate on terms that make sense to those subject to them. ${ }^{60}$ If political institutions are to operate in non-arbitrary ways they must appear acceptable to all reasonable citizens as reflecting the public political culture of the society concerned. Within these accounts, a political society cannot be regarded simply as a voluntary association of convenience among a group of individuals that are sufficiently colocated, numerous and wealthy for their being members of the same political unit to be plausible in functional terms. These individuals must relate to each other in ways that make them a 'people'. ${ }^{61} \mathrm{~A}$ people of the requisite kind arises in part from having certain shared interests through participating in what Rawls called 'a cooperative venture for mutual advantage'. ${ }^{62}$ In other words, their interactions and dependence on each other have a certain intensity of a kind that gives them a roughly equal stake in the collective good of the political society. Yet, as important in shaping their social cooperation as shared interests are shared ideas or a set of common reasons about the appropriate ways to order the collective organisation of their affairs.

Neither shared interests nor shared ideas imply a lack of conflict about either. Merely that a basis exists for a people to reach agreement or agree to disagree through fair and equitable democratic procedures. Communitarians conceive democratic decision-making as

\footnotetext{
${ }^{59}$ L Wenar, 'Why Rawls is not a Cosmopolitan Egalitarian' in R Martin and DA Reidy (eds), Rawls's Law of Peoples: A Realistic Utopia? (Oxford, Blackwell, 2006) 108-09.

${ }^{60}$ eg Walzer, Spheres of Justice (n 38) 28-29.

${ }^{61}$ See Pettit's analysis of the 'ontology of the people' in J Rawls, The Law of Peoples (Cambridge, MA, Harvard University Press, 1999): P Pettit, 'Rawls's Peoples' in R Martin and DA Reidy (eds), Rawls's Law of Peoples: A Realistic Utopia? (Oxford, Blackwell, 2006) 41.

${ }^{62}$ J Rawls, A Theory of Justice (Oxford, Oxford University Press, 1971) 4.
} 
being as much about deliberation on the common good as a mechanism for the aggregation of individual interests. They contend that for democratic processes to possess this quality they must operate among a people or demos possessing the two qualities described above. The sense of a common fate and purposes promoted by mutually beneficial reciprocal interactions help facilitate compromise and the avoidance of a purely self-regarding stance. As a result, minorities are more disposed to accept majority decisions, for example, and, perhaps most importantly, majorities to take into account the opinions and concerns of minorities rather than excluding them altogether. ${ }^{63}$

Democracy so conceived operates as a forum of principle. ${ }^{64}$ The interests and values of diverse groups can be expressed on an equal basis, and the implications of different claims and views placed in the context of the whole range of policies being undertaken by the government and the wider needs and wishes of citizens. For example, conflicting accounts of rights can be weighed and balanced against each other in ways that show equal concern and respect for the individual autonomy of others. So too can different conceptions of social justice that seek to determine what is owed to who by whom, and in which circumstances. The crucial factor, though, comes from these collective decisions being perceived by those on all sides of the argument as somehow 'theirs' - as decisions made in common because those involved are more or less equally affected by the totality of the outcomes, if not each and every decision; draw on a common stock of norms when discussing and evaluating them, even if they disagree about their respective weighting and interpretation; and possess a degree of mutual solidarity as fellow citizens in a shared social enterprise. ${ }^{65}$

It is no accident that the two paradigmatic examples of constitution-making, namely France and the United States in the eighteenth-century, were simultaneously instances of state- and nation-building as well. In the terminology I have been using, the polity dimensions stemming from state sovereignty and a people provided the context for establishing a regime characterised by democracy and the rule of law. Law and democracy

\footnotetext{
${ }^{63}$ Miller (n 8) 96-99; Miller 'Democracy’s Domain' (n 18).

${ }^{64}$ Walzer, 'Philosophy and Democracy' (n 37).

65 eg M Sandel, 'The Political Theory of the Procedural Republic' in G Bryner and N Reynolds (eds), Constitutionalism and Rights (Provo, Utah, Brigham Young University Press, 1987).
} 
cannot boot-strap and provide the source of their own polity conditions. They imply a people who are entitled to make and enforce decisions within a given domain. As a result, the communitarian ghost always lurks within the cosmopolitan machine.

When rights and obligations are nested within particular political communities in this way, their cosmopolitan reach will be affected. To the extent that our understanding of basic rights is coloured by the culture of our community, there are likely to be conflicts between the priorities and publicly recognised needs of different societies. State support for certain religions or languages may be important in some communities and regarded as illegitimate in others, for example. Even when the same rights are acknowledged, variations in local context may lead them to being interpreted and balanced in contrasting and not always compatible ways. In addition, there will be a feeling that 'charity begins at home' that will set limits on how much people will commit themselves to helping outsiders when that clashes with programmes, also motivated by rights considerations, of a domestic character. Thus, communitarians regard it as legitimate that a more generous national social security system, say, might be established at the cost of less spending on foreign aid overseas. ${ }^{66}$

Support for national and state sovereignty need not entail a view of international relations as an anarchic and amoral Hobbesian state of nature. Claims to self-determination for one group imply recognition of similar rights by others - including non-aggression and limited aid. ${ }^{67}$ To the extent that global interdependence does link states within institutional networks, then they will have the sorts of obligations cosmopolitans advocate. Nonetheless, the absence of agreed metrics as to the value of resources or the relative worth of various rights and liberties will make arguments for a global redistribution of goods and services hard to cash out in practice - especially as such schemes can conflict with as well as support the autonomy of national political communities. Still, it is reasonable to suppose that globalisation will produce forms of inter-state cooperation in those areas such as defence, the environment and the economy where the capacity of states to act in autonomous ways has been seriously impaired. International law and organisations emerge from this account as an

\footnotetext{
${ }^{66}$ Miller (n 8) ch 3 and 100-03; D Miller, National Responsibility and Global Justice (Oxford, Oxford University Press, 2007).

${ }^{67}$ Rawls, Law of Peoples (n 60).
} 
international regime that presupposes the existence of polities that have the capacity to represent and act for their peoples. The EU simply provides a particularly significant and developed form of such international cooperation. However, these cooperative schemes should be regarded as mechanisms for preserving rather than undermining national interests and self-determination, with transfers of decision-making power being largely conditional on the extent to which involvement in the relevant international body makes that possible. ${ }^{68}$

\section{Justice and Legitimacy}

So far I have presented the two models in ways that accentuate their differences. They seem divided along two main, if related, dimensions. On the one hand, cosmopolitans argue for the global application of egalitarian theories of justice, whereas communitarians deny this possibility and insist that such theories can only apply within a political community of the kind that does not exist at the global level. On the other hand, cosmopolitans contend that international law provides the basis for a transnational democratic regime divorced from any given polity and that separates popular from state sovereignty. By contrast, communitarians contend that a democratic and legal regime is necessarily embedded within a polity that combines national and state sovereignty, and that international law is consequently inter-state rather than cosmopolitan law. As we have seen, these two models give rise in their turn to quite different images of the EU. Whereas the first suggests it provides a new kind of post-, trans-, or supranational regime without a polity, the second suggests that it must either develop polity-like characteristics or remain an essentially intergovernmental regime.

In this section, I wish to suggest that in one respect these two models are complementary and can be - indeed, need to be - combined, in ways that I shall explore in the concluding section. This complementarity arises from the two models applying different but related standards to the global order, the one stemming from justice and the other from legitimacy. Cosmopolitans tend to fold the second into the first, communitarians the first into the second. However, each requires the other. As we noted above, justice indicates the moral

\footnotetext{
${ }^{68}$ Miller (n 8) 104-08.
} 
entitlements of individuals, and hence what they are owed by others and more especially by the political institutions to which they must submit. By contrast, legitimacy concerns not what individuals are entitled to but rather what entitles political institutions to rule or exercise power over them. These are distinct standards. Egalitarians may regard a political system, such as that of most Member States, as failing to meet certain standards of justice, falling short of their preferred criteria for establishing equal opportunity, for example, and still accept it as legitimate on other grounds.

One way of construing this distinction is to view justice and legitimacy as involving different kinds of equality of respect. ${ }^{69}$ Justice requires that individuals are treated as substantively equal in some respect, be it with regard to access to opportunities, resources or, more minimally, and in a way that need not be egalitarian except in largely formal terms, with regard to certain basic rights. Legitimacy requires that individuals are treated as procedurally equal in some respect, maximally in each consenting to a given arrangement, more minimally in each having an equal say in influencing and accepting it. Both forms of procedural equality can be realised via some form of democratic process.

We saw how certain cosmopolitan theories treat legitimacy as a sub-category of justice. On this account, a system is legitimate to the extent that it satisfies certain minimum substantive distributive standards, including those required for the exercise of certain procedural rights. Moreover, a system becomes illegitimate to the extent democratic procedures violated these basic standards, which thereby need to be locked in through a legal constitution capable of trumping democratic decision-making. Yet treating legitimacy as a component of justice raises a number of problems. For example, how are we to distinguish those elements of justice that provide the threshold for legitimacy from those that are either unnecessary or insufficient to generate it? And does that mean that democratic decisionmaking that respects that threshold ought to be accepted as just, even if the decision itself is in other respects unjust?

Developing an argument of Jeremy Waldron, Laura Valentini has proposed a resolution of this puzzle via a distinction between the 'circumstances of justice' and the

\footnotetext{
${ }^{69}$ Valentini, 'Assessing the Global Order' (n 19).
} 
'circumstances of legitimacy'; ${ }^{70}$ the latter reflecting what Waldron refers to more broadly as the 'circumstances of politics'. ${ }^{71}$ As Rawls, following Hume, noted, the 'circumstances of justice' indicate the need for a collective distributive rule in a condition of moderate scarcity, so not everybody can have everything they want, and limited altruism, so all cannot be expected to spontaneously honour their obligations to others where required to do so. ${ }^{72}$ However, as Waldron pointed out, we perforce must reach agreement on a just distributive rule in circumstances of pervasive disagreement about justice and, it might be added, uncertainty and fallibility in implementing any rule we may agree on. Putting the two together, one can say that while justice requires we acknowledge that human beings have rights and deserve equal treatment, legitimacy requires that we have an equal say when collectively deciding on which rights and what kind of equality are appropriate for us and apply to given cases.

The circumstances of justice and the circumstances of legitimacy prove mutually supporting. Legitimacy entails standards of justice, yet given disagreement over these standards they likewise entail legitimacy. Or to put it in other terms, claims to substantive equality must be both raised and agreed upon within, while also being presupposed by, processes that enshrine procedural equality. If justice and, given ought implies can, feasibility provide what might be called the 'objective' normative and empirical conditions for any political arrangement, then legitimacy offers their 'subjective' normative and empirical conditions - it provides the ways these notions of justice and feasibility make sense to those to whom they apply. In the absence of any clear epistemology to ground our different ontological claims, the two must always go hand in hand. As a result, a political order must relate issues of justice and legitimacy at both the 'polity' and 'regime' dimension as is summarised in Figure 1 below: ${ }^{73}$

\footnotetext{
70 ibid 598.

${ }^{71}$ Waldron, Law and Disagreement (n 20) 159-60.

${ }^{72}$ Rawls, A Theory of Justice (n 61) 126-30

${ }^{73}$ This figure, and the argument supporting it, is adapted from R Bellamy and D Castiglione, 'Legitimising the Euro-polity and its Regime: The Normative Turn in EU Studies' (2003) 2(1) European Journal of Political Theory 7.
} 
Figure 1 The Relations of Justice and Legitimacy

\begin{tabular}{|c|c|c|}
\hline Legitimacy & $\begin{array}{c}\text { Polity (Sphere and } \\
\text { Subjects) }\end{array}$ & Regime (Scope and Styles) \\
\hline $\begin{array}{l}\text { a) socially accepted } \\
\text { norms }\end{array}$ & $\begin{array}{l}\text { Political identification } \\
\text { amongst subjects and } \\
\text { between them and a } \\
\text { particular power centre as } \\
\text { having authority within a } \\
\text { given sphere (be it } \\
\text { territorial, functional or } \\
\text { both) }\end{array}$ & $\begin{array}{l}\text { Institutions recognise } \\
\text { ideals, interests and } \\
\text { identities of governed }\end{array}$ \\
\hline $\begin{array}{l}\text { b) authorisation by } \\
\text { (usually indirect) } \\
\text { consent }\end{array}$ & $\begin{array}{l}\text { As in plebiscites and } \\
\text { referendums over such } \\
\text { issues as secession }\end{array}$ & $\begin{array}{l}\text { Collective decisions seen as } \\
\text { authoritative because } \\
\text { involve mutual recognition }\end{array}$ \\
\hline \multicolumn{3}{|l|}{ Justice } \\
\hline $\begin{array}{l}\text { a) procedural - } \\
\text { established rules }\end{array}$ & $\begin{array}{l}\text { De jure compatible with } \\
\text { international law }\end{array}$ & $\begin{array}{l}\text { Legality - a regular system } \\
\text { of governance/not arbitrary }\end{array}$ \\
\hline $\begin{array}{l}\text { b) substantive - freedom, } \\
\text { justice, efficiency/benefits }\end{array}$ & $\begin{array}{l}\text { Viable, existence does not } \\
\text { entail oppression of } \\
\text { outsiders }\end{array}$ & $\begin{array}{l}\text { Not oppressive, unjust or } \\
\text { incompetent }\end{array}$ \\
\hline
\end{tabular}


Relating this discussion to the earlier contrast between cosmopolitanism and communitarianism, we can see how the two are similarly linked. The first refers to the global circumstances of justice, the second to the national and state-bound circumstances of legitimacy. The former raises issues of justice and of feasibility that provide the normative and empirical requirements on any political system operating in global circumstances. The latter concerns the ways in which people relate to these requirements. A corollary of this linkage is that the attempt to make cosmopolitan norms the basis of a self-validating regime operating outside any given polity will not work. A regime cannot be accepted simply because it promotes justice and efficiency because both of those issues will be in play within any decision-making process. The issue will be for whom and for which purposes are certain issues to be judged just and efficient, and by what process is agreement to be reached. As a result, cosmopolitanism cannot transcend communitarianism - rather cosmopolitanism always implies a communitarian framework within which issues of justice and legitimacy can be related. It remains to be seen how the two may come together, both in general and in the context of the EU.

\section{A Cosmopolitan Communitarianism?}

As we have seen, it is mistaken to regard the cosmopolitan and the communitarian arguments as totally at odds with each other, with the latter anti-liberal, anti-rights and anti-individualist, as certain commentators have claimed. ${ }^{74}$ Rather, they offer contrasting but to some degree compatible accounts of how we should think about individuality, rights and their relationship to the political societies that embody them. My claim will be that cosmopolitan morality only makes sense to the extent that it is embedded within a communitarian framework: a position I dub cosmopolitan communitarianism.

In the last section I suggested that communitarianism supported the processes of legitimation needed to generate and justify agreement to cosmopolitan norms of justice. This

\footnotetext{
${ }^{74}$ eg S Holmes, The Anatomy of Antiliberalism (Cambridge, Harvard University Press, 1993).
} 
argument follows from a more general point, whereby norms of justice need to be embedded in a social and moral context that reflects a web of mutual relations. As we saw, Pogge's interactional approach partly reflects this circumstance. But these interactions consist not just of shared practices but also shared understandings about the nature of those practices.

Following Michael Walzer, one can characterise the difference between the two schools of thought in terms of a distinction between 'thick' and 'thin' moralities. ${ }^{75}$ In his terms, universal human rights represent a 'thin', 'minimal' morality that all societies ought to uphold. But they do so in numerous 'thick', 'maximal' ways. Moreover, the individual rights bearers are similarly contextually defined. That is not to deny value-individualism, as is sometimes implied, but it is to reject those versions of methodological individualism that ignore the social dimension of personal identity and the development of autonomy. ${ }^{76}$ According to this thicker, more communitarian, view of rights and the individual, a pure cosmopolitanism offers an inadequate account of moral agency. For the cosmopolitan, universalist agents are supposed to act on the basis of rational considerations of pure principle that abstract from their sense of identity as persons holding certain convictions and possessing particular attachments. By contrast, the cosmopolitan communitarian believes that both the principles and the moral motivations and character of those who follow them need to be fleshed out with natural sentiments and 'thick' concepts such as courage, honesty, gratitude and benevolence that arise out of specific ways of life.

On its own, cosmopolitanism cannot generate the full range of obligations its advocates generally wish to ascribe to it. For the proper acknowledgement of 'thin' basic rights rests on their being specified and overlaid by a 'thicker' web of special obligations. Welfare states, for example, have typically arisen in societies where there are strong feelings of social solidarity. These reinforce the formal obligations that arise from being members of an institutionalised scheme of political cooperation as citizens of the same state. Essentially, they create a sense of identification amongst a given group of people between whom it comes to be felt both legitimate and plausible that collectively binding decisions about the

\footnotetext{
${ }^{75} \mathrm{M}$ Walzer, Thick and Thin: Moral Argument at Home and Abroad (Notre Dame, University of Notre Dame Press, 1994) esp ch 1.

${ }^{76}$ See Tamir, Liberal Nationalism (n 8) ch 1 for a criticism of such views.
} 
distribution of burdens and benefits should take place. That sense of commonness does not determine what its precise implications or content should be, but it does provide the basis on which such determination takes place. It defines the demos, as it were, for whom a form of democratic rule appears appropriate and plausible and among whom a process giving each an equal say in overcoming their disagreements has come to be understood as both legitimate and legitimising.

Nationalism has traditionally provided the ideological glue necessary to define a relatively circumscribed group of people and unify them around a set of shared institutions and practices that were sovereign over a well-defined territory. Political loyalty, accountability and legitimacy were tied in this way to state power and authority. Indeed, nationality was typically the creation of states and political elites seeking to consolidate their hold over their populations. Cosmopolitans deny the necessity and desirability of such attachments. They may, as Thomas Pogge does, grant them a certain empirical weight but not any moral significance. A mixture of voluntarist and utilitarian considerations of a broadly functional kind provide the only normatively relevant considerations so far as people's obligations to any particular polity are concerned. ${ }^{77}$ By contrast, the earlier sketch of the communitarian argument suggested that largely unchosen commonalties of history, belief, geography and civic culture do have an ethical relevance. They supply the feelings of reciprocity, trust and commitment needed to supplement the ties of mere mutual advantage that result from individuals acting on the basis of rational self-interest alone. Such moral qualities have an important influence on the character of political life, since they increase people's willingness to engage in cooperative behaviour by raising their expectations and confidence in others. As David Miller has argued, ${ }^{78}$ far from encouraging self-interested and partial behaviour, the lessening of the tension between personal and collective goals within a group is likely to make an impartial stance more acceptable.

\footnotetext{
${ }^{77}$ AJ Simmons, Moral Principles and Political Obligation (Princeton, Princeton University Press, 1979).

${ }^{78}$ Miller (n 8) Ch 2.
} 
What are the implications of this analysis for the EU? Figure 2 explores four possible combinations: ${ }^{79}$

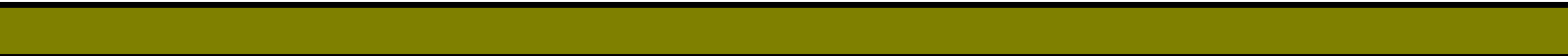

Figure 2 The Political Ontology of the EU

\begin{tabular}{|l|l|l|}
\hline & \multicolumn{1}{|c|}{ COMMUNITARIANISM } & \multicolumn{1}{c|}{ COSMOPOLITANISM } \\
\hline COSMOPOLITAN & $\begin{array}{l}\text { Cosmopolitan } \\
\text { Communitarianism }\end{array}$ & $\begin{array}{l}\text { Cosmopolitan Globalism } \\
\text { World market, international } \\
\text { law based on human rights. } \\
\text { Aost national federalism } \\
\text { A civic Europe of multiple } \\
\text { communities involving } \\
\text { variable geometry }\end{array}$ \\
$\begin{array}{l}\text { Functional parcelling out of } \\
\text { sovereignty } \\
\text { (Exists in both social liberal } \\
\text { and libertarian versions) }\end{array}$ \\
\hline
\end{tabular}

79 This figure is adapted from R Bellamy and D Castiglione, 'Debate: Lacroix's European Constitutional Patriotism: A Response’ (2004) 52 Political Studies 187. 


\begin{tabular}{|l|l|l|}
\hline COMMUNITARIAN & Civic/Ethnic Nationalism & Communitarian \\
Strong nationalists of various & Cosmopolitanism \\
kinds, whose civic attitudes & Supranational federalism \\
are predominantly to those of & \\
their variously described & \\
national groups. & European civic nation \\
& $\begin{array}{l}\text { Include Eurosceptics, on the } \\
\text { one hand, and } \\
\text { supranationalists seeking a } \\
\text { European nationalism, on the } \\
\text { other. }\end{array}$ \\
\hline
\end{tabular}

These positions can be characterised as 'ideal types' and each of them involves both pro- and more sceptical and even anti-EU positions. I have suggested that the rival theories occupying the top right hand (pure cosmopolitan) box cannot legitimate and validate their various claims to justice, or even sustain the relationships needed to support their particular accounts of just relations. The normative aspect of the cosmopolitan argument will only go beyond a 'thin' humanitarian concern for others to the extent we live in a relatively 'thick' cosmopolitan civil society with a corresponding public culture.

That leaves three possibilities. We may characterise these as involving (moving anticlockwise from the bottom left, pure communitarian, box): (1) a Europe of separate, independent democratic nation-states, characterised by ethnic nationalism (or an ethnic national Europe of a similar autarchic nature vis-à-vis the rest of the world, although this is more a theoretical than a real possibility); (2) a civic European nation based around supranationalism (the communitarian cosmopolitan vision); or (3) (moving to the top left, cosmopolitan communitarian box) a civic Europe that operates as a Union of nation-states and involves a degree of variable geometry combined with a fair amount of consensus on central issues and even certain elements of a common identity.

Once again these models combine empirical and normative aspects and so can be evaluated for their plausibility and desirability. The first need not be undesirable, though 
there are xenophobic versions that are. It potentially allows for a degree of pluralism among states, that respects cultural differences between and self-determination within them, yet allows for global inequalities that a cosmopolitan egalitarian would deplore. Per se that need not pose a problem of justice if each of these states respects rights and democracy, substantive and procedural equality, for all their citizens along the lines defended here. The difficulty arises from the fact that this model assumes a degree of homogeneity within these states and a lack of connection between them that is implausible in today's globalised and multicultural societies. Interdependence may not have completely subverted state autonomy, as some globalists contend, but they have undeniably weakened it. Not only do the decisions of states impact on the decision-making capacity of other states in numerous ways, but also so do the transnational activities of numerous non-state actors, from organised crime to large corporations and financial institutions.

The second assumes a degree of internal cohesion and identification at the EU level a commonality of values and of interests - that I have doubted exists or is likely to exist. The neo-functionalist federalist line greatly overestimates the integrative potential of global forces and the capacity of people to transfer their allegiances. However, as, if not more important, than these potentially superable empirical objections is the normative objection to the loss involved in diminishing the capacity for people to determine their own lives in the light of a shared culture and history. As we saw, such values prove important in legitimising the common agreements and solidarity on which implementing justice depends.

That leaves the third position. This position involves a rejection not only of an unqualified cosmopolitan globalism and universalism, but also of the centralised federalist version of the cosmopolitan argument and the Eurosceptical version of the communitarian case. The cosmopolitan communitarian position involves civic nations demonstrating civic attitudes not only internally but also to a greater or lesser extent externally, with basic 'thin' cosmopolitan sentiments thickening in various ways depending on the nature and degree of their interaction and involvement with other nations and even international allegiances possibly developing in some instances. The civic nation variant of the communitarian argument is extended in this way to accommodate aspects of both the globalisation thesis and a universal cosmopolitan morality, whilst denying the normative desirability or empirical 
possibility of a European, let alone a global, civic nation. As I have argued elsewhere, ${ }^{80}$ it allows for an 'ever closer union of European peoples', including the development of common political and economic institutions. Yet these are best conceived not as supranational but as inter-national, delegated authorities, and under their equal and shared control. ${ }^{81}$

A detailed outline of the institutional arrangements or regime that follow from this model lies outside the scope of this chapter. ${ }^{82}$ Here I have simply sought to define the ontological 'polity' conditions of an EU that is capable of uniting the claims of global justice and functional requirements associated with cosmopolitanism and the legitimacy claims and democratic demands for communal self-rule insisted upon by communitarians. Since the financial crisis the tensions between the two have grown, making it ever more unlikely that these conflicting claims can be met within a federal EU polity that attracts increasing distrust across the Member States. ${ }^{83}$ The argument of this chapter has been that the ontological ground for their reconciliation lies in pursuing the alternative of a Union of self-governing, democratic nation-states.

${ }^{80}$ R Bellamy, 'An Ever Closer Union of Peoples: Republican Intergovernmentalism, Demoi-cracy and Representation in the EU' (2013) 35(5) Journal of European Integration 499.

${ }^{81} \mathrm{P}$ Lindseth, Power and Legitimacy: Reconciling Europe and the Nation State (Oxford, Oxford University Press, 2010).

${ }^{82}$ For a sketch, see Bellamy and D Castiglione, 'Three Models of Democracy, Political Community and Representation in the EU' (n 11).

${ }^{83}$ M Matthijs,'Mediterranean Blues: The Crisis in Southern Europe' (2014) 25(1) Journal of Democracy 101. 